\title{
Effect Carrier Materials of Bradyrhizobium sp. strain PZS_A08 on Growth of Indigofera zollingeriana
}

\author{
Wilhelmus Terang Arga Sanjaya ${ }^{1 *}$, Sari Yulia Kartika ${ }^{1,3}$, Desak Ketut Tristiana Sukmadewi ${ }^{1,2}$, \\ Rahayu Widyastuti ${ }^{1}$ and Iswandi Anas Chaniago \\ ${ }^{1}$ Department of Soil Science and Land Resources, Faculty of Agriculture, IPB University (Bogor Agricultural \\ University), Bogor, Indonesia. ${ }^{2}$ Faculty of Agriculture, Warmadewa University, Denpasar, Indonesia. \\ ${ }^{3}$ Pat Petulai University, Bengkulu, Indonesia. \\ *e-mail: wilhelmus_arga@apps.ipb.ac.id
}

Received March 31, 2021; Revised May 04, 2021; Accepted 31 May 2021

\begin{abstract}
Sustainable forage production is needed to meet animal feed needs as the livestock industry increases. The purpose of this study was to evaluate the effect of liquid and solid carrier material on the effectiveness and infectivity of Bradyrhizobium sp. strain PZS_A08 on the growth of Indigofera zollingeriana (I. zollingeriana). This study used two carrier materials consisting of zeolite (solid) and molasses (liquid). The five treatments given were P0 (50\% NPK), P1 (50\% NPK+liquid biofertilizer), P2 (50\% NPK+sterile liquid biofertilizer), P3 (50\% NPK+solid biofertilizer), P4 (50\% NPK+sterile solid biofertilizer), P5 (100\% NPK). The research was conducted in a Completely Randomized Design (CRD) consisting of 6 treatments and four replications. Observations were made on the plant's height, number of leaves, number of nodules, upper parts and root wet biomass, root and upper parts dry biomass, root length, and microbial population). The use of liquid and solid carrier materials effectively affected the effectiveness and infectivity of Bradyrhizobium sp. strain PZS_A08 on I. zollingeriana. Inoculants Bradyrhizobium sp. strain PZS_A08 significantly increased plants' growth and reduced the use of 50\% NPK fertilizer. Cold storage temperature $\left(5^{\circ} \mathrm{C}\right)$ effectively maintained Bradyrhizobium sp. strain PZS_A08 on liquid and solid carriers, while solid carriers showed better effectiveness at room temperature storage $\left(30^{\circ} \mathrm{C}\right)$. Through this research, solid carriers such as zeolite are recommended as carriers for Bradyrhizobium sp. filter PZS_A08.
\end{abstract}

Keywords: Biofertilizer, Bradyrhizobium, Carrier, I. zollingeriana, Nitrogen-fixing bacteria

\section{INTRODUCTION}

Continuous forage production is needed to meet livestock industry needs (Duan et al. 2019). Fluctuating quantity and quality of feed, especially during the dry season (Tinsley et al. 2019), decrease livestock productivity (Tabacco et al. 2018). It also impacts the high mortality rate and the low livestock growth rate. Therefore forage feed, a combination of grass and legume, is needed to complement the nutrients required by livestock (Duan et al. 2019; Koten et al. 2014). I. Zollingeriana feed plants are potential feed crops as supplementary feed ingredients to improve livestock's nutritional status on cattle, goats, and poultry (Devendra and Liang 2012; Faradillah et al. 2015). Indigofera can

J Trop Soils, Vol. 26, No. 2, 2021: 95-103

ISSN 0852-257X ; E-ISSN 2086-6682 produce forages up to 7.9 tons in one harvest, with a protein content of around $24 \%$ per dry weight. Indigofera $\mathrm{sp}$. can be a source of forage for ruminants because it has high nutritional quality and productivity (Hassen et al. 2008). This plant can be used as a protein and energy source because of the relatively high nitrogen content and digestibility of dry matter and organic matter. Simanuhuruk and Sirait (2009) reported that Indigofera sp. has the potential a basal feed in the grass for goats based on chemical composition analysis, consumption means of dry feed matter, live weight gain, and feed utilization efficiency. Tarigan and Ginting (2011) stated that the level of Indigofera sp. used in rations given to goats could increase the study's optimal response by $30-45 \%$. Based on Nurhayu and Pasambe (2016), it was reported that Indigofera fed for beef cattle feed at the rate of $40 \%-60 \%$ increased the bodyweight of beef cattle and reduced 
feed conversion. Indigofera sp. can also be processed into flour and used as a poultry ration mixture. It can improve the quality of eggs physically and chemically (Faradillah et al. 2015).

Although studies related to the potential and composition of I. zollingeriana have been widely carried out, the development to improve forage yield and biomass productivity has not been explored. Abdullah et al. (2011) have applied liquid urine as organic liquid fertilizer on I. zollingeriana plants to improve agronomic performance. Hutapea et al. (2018) have increased I. zollingeriana and increased the methionine level by inoculating nitrogen-fixing bacteria. This study obtained that Bradyrhizobium sp. strain PZS_A08 are the most effective bacteria in increasing I. zollingeriana biomass production by $27,9 \%$. Although the positive effect of Bradyrhizobium sp. strain PZS_A08 has been reported, research on the formulation has not been carried out. One crucial factor in ensuring a good formulation process and producing high-quality biofertilizer is carrier material suitability. A suitable carrier will support bacteria viability and provide an optimum condition for preserving the bacteria population. A suitable carrier should be nontoxic, sterilizable, nonreactive, rich in organic matter, and have a solid moisture-holding capacity. So far, there are two carriers developed for biofertilizer formulations, consisted of solid and liquid carriers. Even though liquid biofertilizer formulations have been claimed to have better survival and nodulation, their use depends on the type of bacteria used and the methods used to colonize the soil and plants (Shravani et al. 2019). As carrier material, molasses and zeolite are often used for biofertilizer formulations, especially those containing $\mathrm{N}$-fixing bacteria. Leggo (2015) has reported that zeolite use could support nitrification processes. The mineral surface of zeolite absorbed ammonium ions provided organic waste degradation processes, thus avoiding nitrogen loss to the atmosphere by volatilization. It allows more ammonium oxidation of nutrients by soil nitrifying microorganisms.

On the other hand, molasses as liquid biofertilizers are an excellent source of carbon, energy, and fermentative sugars, supporting bacteria multiplication (Garcha et al. 2019). Furthermore, the carrier media is used to pack the biological agent, prolong the shelf life of biological agents, grow the inoculum, maintain the bacteria's viability before the infection process, and form nodules (Brar et al. 2012). Thus, the carrier material aspect is highly critical in mass production to guarantee biofertilizer quality.
Therefore, the purpose of this study was to evaluate the effect of liquid and solid carrier material on the effectiveness and infectivity of Bradyrhizobium sp. strain PZS_A08 on the growth of I. zollingeriana.

\section{MATERIALS AND METHODS}

\section{Study Site}

This research was carried out in March 2018 until May 2018 at the Laboratory of Soil and Environmental Biotechnology, Department of Soil Science and Land Resources, Faculty of Agriculture IPB (Bogor Agricultural University) Cikabayan Experimental Greenhouse, IPB. I. zollingeriana plant seeds were obtained from the Laboratory of Feed Science and Technology, Faculty of Animal Husbandry, Bogor Agricultural University. Latosol soil was used as planting media in the experiment. In contrast, Bradyrhizobium sp. strain PZS_A08 was obtained from a previous study (Hutapea et al. 2018). The other material used consisted of essential fertilizers (Urea, Tri Calcium Phosphate (TSP), Potassium Chloride $(\mathrm{KCl})$ ), zeolite with $4 \%$ moisture content, and molasses.

\section{Bradyrhizobium Isolates Preparation}

Bradyrhizobium sp. strain PZS_A08 was rejuvenated using Yeast Extract Mannitol Agar (YEMA) media, consisting of $10 \mathrm{~g}$ of mannitol; 0.5 $\mathrm{g}$ of yeast extract; $0.5 \mathrm{~g} \mathrm{~K}_{2} \mathrm{HPO}_{4} ; 0.2 \mathrm{~g} \mathrm{MgSO}_{4}$, $7 \mathrm{H}_{2} \mathrm{O} ; 0.1 \mathrm{~g} \mathrm{NaCl} ; 20 \mathrm{~g}$ of bacto agar in one liter of water. Then it was incubated for 24 to 48 hours at $30{ }^{\circ} \mathrm{C}$. The growing isolates were subjected to a series of tests, including a hypersensitivity test using tobacco plants and a hemolysis test using blood agar.

\section{Preparation of Biofertilizers}

Biofertilizers containing microbial Bradyrhizobium sp. strain PZS_A08 were created aseptically in solid (zeolite) and liquid (molasses) carrier materials. The volume ratio between the carrier and bacteria inoculum used was 5:1. Before inoculating the carrier material, the microbes population was equated up to $10^{-7}$. Each biofertilizer was incubated at $30^{\circ} \mathrm{C}$ and refrigerator temperature of $5^{\circ} \mathrm{C}$ to evaluate its viability level.

The planting medium used was Latosol soil taken from the Cikabayan experimental field, Agricultural University of Bogor. The soil was airdried, then sieved using a two mesh sieve. The sifted soil was put into pots and added with essential fertilizer (Urea, TSP, KCl). Some samples were 
taken for the initial soil analysis, water content, field capacity, and $\mathrm{pH}$.

\section{Planting and Maintenance}

The one-month-old I. zollingeriana plant seeds that had grown well and had the same height were chosen and transferred to the prepared planting medium. Before planting, TPC (Total plate Count) calculation was conducted on the carrier material used. The population of Bradyrhizobium sp. strain PZS_A08 applied was $3.8 \times 10^{11} \mathrm{CFU} \mathrm{m}^{-1}$ on a molasses carrier material and $4 \times 10^{11} \mathrm{CFU} \mathrm{g}^{-1}$ on zeolite carrier materials.

Maintenance activities included daily watering to keep the media moist. In addition, physical cleaning of weeds and pests was carried out. Finally, fertilization was done on the plants after 1 MST, and fertilization was given according to the treatment.

\section{Plant Growth Observation}

In this study, plant height measurements, the number of leaves, and the stems were conducted once a week for four weeks. In the final stage of observation, the plant height, number of leaves, number of branches, number of root nodules, upper and lower biomass, upper and lower dry weight, root length, and microbial population calculation (Total Plate Count) were conducted.

\section{Experimental Design and Data Analysis}

The research was conducted in a Completely Randomized Design (CRD) consisting of 6
Table 1. Types of treatment used.

\begin{tabular}{cl}
\hline Treatment & Description \\
\hline P0 & $50 \%(\mathrm{NPK})$ \\
P1 & $50 \%(\mathrm{NPK})+1 \mathrm{ml} \mathrm{pot}^{-1}$ liquid inoculant \\
P2 & $50 \%(\mathrm{NPK})-1 \mathrm{ml} \mathrm{pot}^{-1}$ liquid inoculant \\
P3 & $50 \%(\mathrm{NPK})+5 \mathrm{~g} \mathrm{pot}^{-1}$ solid inoculant \\
P4 & $50 \%(\mathrm{NPK})-5 \mathrm{~g} \mathrm{pot}^{-1}$ solid inoculant \\
P5 & $100 \%(\mathrm{NPK})$ \\
\hline
\end{tabular}

treatments and four replications, so that the total units of the experiment were 24 units. The treatment used is shown in Table 1.

The data obtained were then analyzed by variance. Finally, further analysis was carried out using Duncan Multiple Range Test (DMRT) with the SAS 9.4 program in the treatment.

\section{RESULTS AND DISCUSSION}

Based on preliminary and final soil analysis in Table 2, the organic matter content of the soil has increased in the treatment that gets the addition of biofertilizer, from $2.04 \%$ to $2.11 \%$ (zeolite carrier materials) and $2.12 \%$ (molasse carrier materials). This increase was caused by microbes' biomass as a source of organic matter to the soil, besides enzymatic reactions between plant roots could increase natural properties. The increased $\mathrm{C} / \mathrm{N}$ value supports this in the soil after being given. However, the total measured $\mathrm{N}$ content in the soil also slightly increased. Oliveira et al. (2017) reported that biofertilizers positively impacted nutrient uptake

Table 2. Characteristics of the soil used in the experiment.

\begin{tabular}{|c|c|c|c|}
\hline Parameter & Before treatment & $\begin{array}{c}\text { After treatment } \\
\text { (Inoculant in Zeolite) }\end{array}$ & $\begin{array}{c}\text { After treatment } \\
\text { (Inoculant in Molasses) }\end{array}$ \\
\hline $\mathrm{pH} \mathrm{H} \mathrm{H}_{2} \mathrm{O}$ & 5.44 & 5.48 & 5.45 \\
\hline pH KCL & 4.80 & 4.92 & 4.89 \\
\hline Organic Carbon & $2.04 \%$ & $2.11 \%$ & $2.12 \%$ \\
\hline Total N (N \%) & $0.18 \%$ & $0.27 \%$ & $0.21 \%$ \\
\hline C/N Ratio & 11 & 13 & 13 \\
\hline $\mathrm{P}_{2} \mathrm{O}_{5}$ available & $1.57 \mathrm{ppm}$ & $1.52 \mathrm{ppm}$ & $1.49 \mathrm{ppm}$ \\
\hline $\mathrm{P}_{2} \mathrm{O}_{5}$ potential & $59.08{\mathrm{mg} 100 \mathrm{~g}^{-1}}$ & $58.99{\mathrm{mg} 100 \mathrm{~g}^{-1}}^{-1}$ & $58.78{\mathrm{mg} 100 \mathrm{~g}^{-1}}^{-}$ \\
\hline $\mathrm{K}_{2} \mathrm{O}$ potential & 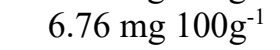 & $6.71 \mathrm{mg} 100 \mathrm{~g}^{-1}$ & $6.81 \mathrm{mg} 100 \mathrm{~g}^{-1}$ \\
\hline $\mathrm{K}^{+}$exchangeable & $0.10 \mathrm{cmol}(+) \mathrm{kg}^{-1}$ & $0.12 \mathrm{cmol}(+) \mathrm{kg}^{-1}$ & $0.10 \mathrm{cmol}(+) \mathrm{kg}^{-1}$ \\
\hline $\mathrm{Na}+$ exchangeable & $0.02 \mathrm{cmol}(+) \mathrm{kg}^{-1}$ & $0.02 \mathrm{cmol}(+) \mathrm{kg}^{-1}$ & $0.02 \mathrm{cmol}(+) \mathrm{kg}^{-1}$ \\
\hline $\mathrm{Ca}^{2+}$ exchangeable & $3.12 \mathrm{cmol}(+) \mathrm{kg}^{-1}$ & $3.19 \mathrm{cmol}(+) \mathrm{kg}^{-1}$ & $3.12 \mathrm{cmol}(+) \mathrm{kg}^{-1}$ \\
\hline $\mathrm{Mg}^{2+}$ exchangeable & $0.47 \mathrm{cmol}(+) \mathrm{kg}^{-1}$ & $0.48 \mathrm{cmol}(+) \mathrm{kg}^{-1}$ & $0.48 \mathrm{cmol}(+) \mathrm{kg}^{-1}$ \\
\hline Cation Exchange Capacity & 16.04 & 16.01 & 16.04 \\
\hline Alkaline saturation & $23.17 \%$ & $23.54 \%$ & $23.54 \%$ \\
\hline $\mathrm{Al}^{3+}$ exchangeable & $0.99 \mathrm{cmol}(+) \mathrm{kg}^{-1}$ & $\left.0.87 \mathrm{cmol}^{(+}\right) \mathrm{kg}^{-1}$ & $0.97 \mathrm{cmol}^{(+)} \mathrm{kg}^{-1}$ \\
\hline $\mathrm{H}^{+}$exchangeable & $0.54 \mathrm{cmol}(+) \mathrm{kg}^{-1}$ & $\left.0.47 \mathrm{cmol}^{(+}\right) \mathrm{kg}^{-1}$ & $\left.0.52 \mathrm{cmol}^{(+}\right) \mathrm{kg}^{-1}$ \\
\hline
\end{tabular}


efficiency. It also increased nutrient availability likes total N, nitrate-N, and ammonium-N. The following data indicate that the increase in the element $\mathrm{C} / \mathrm{N}$ ratio is not caused by a decrease in the element $\mathrm{N}$ in the soil but a significant increase in organic carbon. Based on Dêbska et al. (2016), biofertilizer use increases the permanent humus compounds, correlated with increased soil organic matter stability. Consequently, the contribution of the organic matter fractions that are more resistant to decomposition is crucial for increasing soil carbon sequestration.

Meanwhile, other elements' content is relatively unchanged (phosphate, potassium, calcium, magnesium, and sulfate), including the CEC and soil $\mathrm{pH}$. Thus, apart from the formulation of the carrier material, soil properties also influence the effect of biofertilizers on increasing plant production.

We are interested in this research because there has not been much data to discuss carriers' effect on adding Bradyrhizobium as biofertilizers. The carrier has a crucial role in delivering a suitable amount of microbes in good physiological conditions. As one of the microbes that have an essential role in implementing the $\mathrm{N}$ cycle in the soil, the formulation of $\mathrm{N}$-fixing bacteria biofertilizer has been widely studied to obtain biological fertilizers, increasing the $\mathrm{N}$ content in the soil. Abd El-Fattah et al. (2013) have reported that the use of carriers and sterilization methods will affect the quality of biofertilizers containing Azotobacter chroococcum. The use of the type of carrier material also influences the effectiveness of biofertilizers in terms of the response of the plants produced (Khandare et al. 2015). Mukhtar et al. (2017) suggested that carriers in biofertilizers with phosphate solubilizing bacteria correlated with the increase in wheat yields. Microbes' effectiveness in increasing plant growth correlates with their colonized roots' ability. The suitability factor of the carrier with storage temperature is an essential factor in the production of biological fertilizers because it affects the stability of the population and the microbes' physiological conditions (Kaljeet et al. 2011).

Table 3 shows that the average growth of $I$. zollingeriana for 30 days after planting from 6 treatments tested mostly showed a significant effect on the observed variables. The parameter used in this study was the growth of the plant, which included: plant height, number of leaves, number of leaf stalks, the shoot and root biomass of the plant, dry weight of the upper and lower parts of the plant, number of root nodules, and root length. The treatment by giving the Bradyrhizobium sp. strain PZS_A08 (P1 and P3) showed a considerable influence on plants' vegetative growth compared with the absence of the Bradyrhizobium sp. strain PZS_A08. It indicates that Bradyrhizobium sp. strain PZS_A08 application can increase plants' height growth by $20-70 \%$ compared with giving $100 \%$ NPK fertilizer (P5) only. The positive effect of Bradyrhizobium sp. strain PZS_A08 is also supported by several data, including the number of effective root nodules formed and root biomass, which were higher compared without Bradyrhizobium sp. application. Bradyrhizobium sp. stimulates nodule

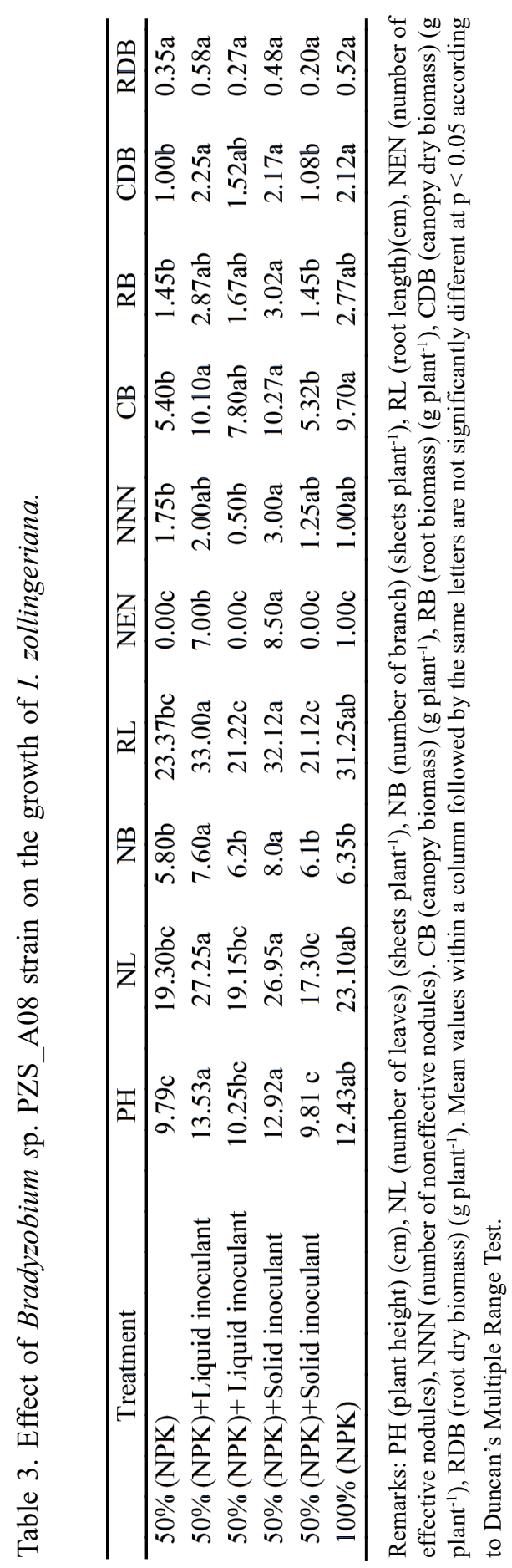


formation, which affects the release of organic compounds into the soil and increases the amount of nitrogen (Gopalakrishnan et al. 2015; Lindström and Mousavi 2020). It also explains why the number of nodules affects the growth in the number of leaves, stems, and root length because of higher nitrogen accessibility.

Table 3 shows that adding Bradyrhizobium inoculant gave significant responses to the amount of biomass and dry weight of the Indigofera zollingeriana. Even though there is no significant difference between zeolite and molasses use, the number of nodules showed a different response because of carriers used. Zeolite's use stimulated better nodulation than molasses, which was revealed through more nodules and root biomass. Plant biomass includes all organic material of the plants from the unit area unity's photosynthesis at a particular time with units of $\mathrm{g} \mathrm{m}^{-2}$. In the $\mathrm{P} 3$ treatment, the number of effective nodules was more than the other treatments, indicating higher nitrogen fixation rates. It is related to nitrogen content in the soil and increases the I. zollingeriana metabolism.

Based on Figure 1, it can be seen that plant height and root length differ among different treatments between the Bradyrhizobium sp. strain PZS_A08 inoculum application and without application. It shows the influence of the application of Bradyrhizobium sp. strain PZS_A08 on plant height and root length. Bradyrhizobium sp. formed nodules symbiotically with Indigofera zollingeriana (I. zollingeriana), impacting plants' growth improvement because nitrogen availability increases. On the other hand, Maróti and Kondorosi (2014) state that the process of root elongation and nodule formation is influenced by the availability of carbohydrates produced from photosynthesis. In legume plants, high concentrations of nitrate and ammonium $(>3 \mathrm{mM})$ can inhibit the nodulation process, while at lower concentrations, it can stimulate nodule formation. Besides, N sources' availability in other forms plays an essential role in the differentiation of plant roots. Under $\mathrm{N}$ deficiency conditions, plants streamline the use of carbon sources and trigger plant root growth to explore nitrogen origin in the soil and initiate symbiosis with N-fixing bacteria (Radzman et al. 2013).

Based on the six treatments tested, most of the plants were able to produce root nodules, whereas in the treatment of liquid biofertilizers without Bradyrhizobium sp. strain PZS_A08 inoculant bacteria, there was only one non-effective root nodule which was formed from each repetition tested, and there was no effective root nodule. In treatment $\mathrm{P} 1$ and $\mathrm{P} 3$, the number of effective root nodules was more significant than $\mathrm{P} 0, \mathrm{P} 2, \mathrm{P} 4$, and P5. It means that Bradyrhizobium sp strain PZS_A08 application can increase the efficiency of effective formation of root nodules and increase the effectiveness of fixing $\mathrm{N}$. It also confirmed that nodule formation was dominantly stimulated by added Bradyrhizobium sp. strain PZS_A08.

Nitrogen-fixing microbes could not permanently inhabit root nodules, even though they exist in the soil. Instead, it depends on microbes' infective ability and environmental factors such as water as providers and competition with other microbes. According to Pommeresche and Hansen (2017), an effective root nodule's characteristic will show pink to the brownish middle when cut transversely. This Leghemeglobin red pigment plays the most significant role in fixing $\mathrm{N}$. The pigment is found in nodules between the bacteroids and the surrounding membrane. Therefore, the amount of leghemoglobin in the root nodules will directly relate to the nitrogenfixed amount.

After harvesting, observations of nodules formed on the roots of I. zollingeriana in the addition of Bradyrhizobium sp. strain PZS_A08 with molasses and zeolite carrier treatment were conducted. Based on the observation results, the
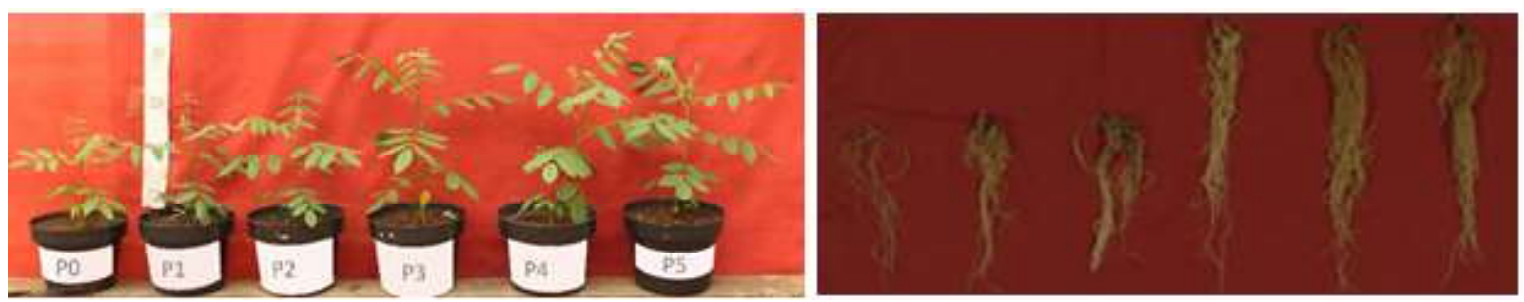

Figure 1. Effect of inoculation with Bradyrhizobium on the growth of I. zollingeriana day 30. Remarks: P0 (50\% NPK), P1 (50\% NPK $+1 \mathrm{ml} \mathrm{pot}^{-1}$ liquid inoculant), P2 (50\% NPK-1 ml pot ${ }^{-1}$ liquid inoculant), P3 (50\% NPK +5 g pot $^{-1}$ solid inoculant), P4 (50\% NPK-5 g pot $^{-1}$ solid inoculant), P5 (100\% NPK). 
size of the root nodules formed ranged from 3 to 5 $\mathrm{mm}$ (Figure 2). This size is smaller than the Bradyrhizobium nodules in general, which have a length ranging from 5-10 $\mathrm{mm}$ for Indigofera (Bünger et al. 2021). Nodulations in other plants such as shrubby sophora (Sophora flavescens) and soybean (Glycine max) are smaller, about 1-3 mm long (Ledermann et al. 2021; Liu et al. 2018). This size is also influenced by the type and age of the plant, where Indigofera has a relatively long life. In this study, nodulation was observed in 2-month-old plants. It caused the growth of nodules to have not yet reached the maximum point.

The form of root nodules tended to be round with a rough surface. Bradyrhizobium, inoculated with molasses, had a spreading nodule located on the central axis and lateral roots. Meanwhile, Bradyrhizobium inoculated through zeolite carriers had relatively more nodules on the central axis than in the first-order lateral roots. The root nodulation was mainly adjacent to the central axis root and was in the lateral roots with a more extensive root diameter. However, the pattern of nodulation is affected by several factors, including plant cultivar and microbial strains. The dynamics of water movement in the soil consisting of filtration and percolation, can also affect soil bacteria colonization, affecting nodule formation (Czaban et al. 2007). Although there was no significant difference in affecting plant biomass production, carrier use was sufficient to influence the number of nodules and the nodule formation pattern. The observation results also showed that the color of effective nodules was red, and they had a relatively larger size than noneffective nodules. It is similar to the study of Nguyen et al. (2017), which shows the appearance of Bradyrhizobium elkanii nodules with a white outer layer and a red inner layer. The bacteria compatibility and genetic factors strongly influence the ability of Bradyrhizobium to infect. The active nodules in fixing N2 will be red because it contains many leghemoglobin (Larrainzar et al. 2020). It also confirmed that the inoculant, either using molasse or zeolite, can infect I. zollingeriana.

Another indicator that can confirm the success of Bradyrhizobium in colonizing the root zone of Indigofera is by observing the bacterial population in the root area. Based on the observations, the bacterial population with zeolite as a carrier could colonize the root area better than the molasses carrier. Inoculants with zeolite carriers could colonize the root area up to $29 \times 10^{6} \mathrm{CFU} \mathrm{ml}^{-1}$, while inoculants with molasses as carriers were up to $5 \times 10^{6} \mathrm{CFU} \mathrm{ml}^{-1}$ (Table 4). Even though inoculation technology has several benefits, it also has a significant limitation on the inoculum survival rate in soil and rhizosphere (Santos et al. 2019). Hence maintaining physiological condition and microbe amount during storage and application period is essential.

The population growth of the Bradyrhizobium sp. strain PZS_A08 in the molasses carrier material was relatively high at room temperature $\left(30^{\circ} \mathrm{C}\right)$, up to $3.87 \times 10^{8} \mathrm{CFU} \mathrm{ml^{-1 }}$ during the first week. However, there was a significant decrease at week six with a $0.31 \times 10^{8} \mathrm{CFU} \mathrm{ml}^{-1}$ population. Meanwhile, the bacteria on the molasses carrier material with a treatment temperature of $5{ }^{\circ} \mathrm{C}$ showed high population density at week six with a population of $3.65 \times 10^{8} \mathrm{CFU} \mathrm{ml}^{-1}$. It indicates that the first week
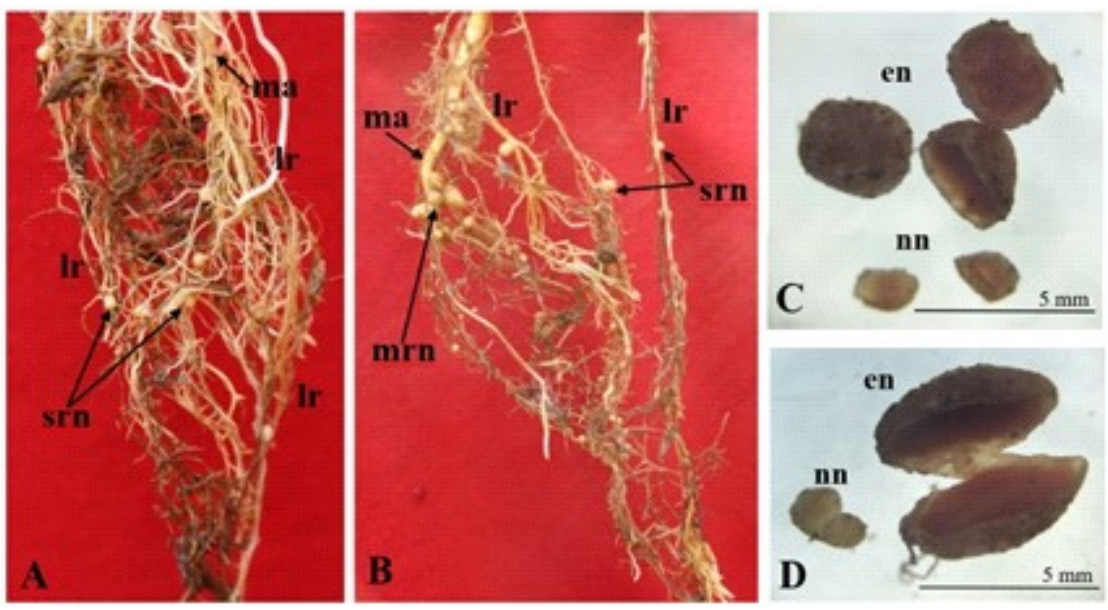

Figure 2. The appearance of Bradyrhizobium sp. strain PZS_A08 root nodules in soil with (a) a liquid carrier (molasses) and (b) a solid carrying material (zeolite). 
Table 4. The population of Bradyrhizobium in the post-harvesting soil.

\begin{tabular}{lc}
\hline Treatment & Population $\left(\mathrm{CFU} \mathrm{ml}{ }^{-1}\right)$ \\
\hline P0 50\% (NPK) & $<10^{5}$ \\
P1 50\% (NPK)+Liquid inoculant & $5 \times 10^{6}$ \\
P2 50\% (NPK)+ Liquid inoculant) & $<10^{5}$ \\
P3 50\% (NPK)+Solid inoculant & $29 \times 10^{6}$ \\
P4 50\% (NPK)+Solid inoculant) & $<10^{5}$ \\
P5 100\% (NPK) & $3.9 \times 10^{6}$ \\
\hline
\end{tabular}

of microbial growth on the molasses medium had entered the exponential phase, and in the sixth week, it entered the phase of death. Store it at $5{ }^{\circ} \mathrm{C}$ was able to maintain the population of Bradyrhizobium sp. strain PZS_A08 up to more than 35 days. Microbes' growth in zeolite carriers exponentially increased in the third week with a population density of $3.91 \times 10^{8} \mathrm{CFU} \mathrm{ml}{ }^{-1}$ at $30^{\circ} \mathrm{C}$ and $3.19 \times 10^{8} \mathrm{CFU}$ $\mathrm{ml}^{-1}$ at a temperature of $5^{\circ} \mathrm{C}$. While the population density decreased in the sixth week at $30^{\circ} \mathrm{C}$, the microbe population at $5{ }^{\circ} \mathrm{C}$ still increased to 3.65 $\times 10^{8} \mathrm{CFU} \mathrm{\textrm {ml } ^ { - 1 }}$ (Figure 3). It shows that zeolite material could preserve inoculant population bettercompared molasses, particularly at room temperature storage.

The level of viability affected the population of Bradyrhizobium sp. strain PZS_A08 applied to the plants and impacted the quality of biofertilizers. In addition, the type of carrier material and the proper environmental conditions significantly affected Bradyrhizobium sp. strain PZS A08 to retain its population. Based on viability data, the bacteria population was relatively more conserve in low temperature, using molasse or zeolite as carrier material. Furthermore, the carriers' ability to maintain bacterial populations over a wide temperature range is essential because biofertilizers cannot always be stored at low temperatures when marketed to consumers (Mohamed et al. 2016). Therefore, based on this study, we recommend using zeolites better to maintain the Bradyrhizobium population at a temperature of $30^{\circ} \mathrm{C}$.

\section{CONCLUSIONS}

The use of both liquid and solid carrier materials effectively influences the effectiveness and penetration of Bradyrhizobium sp. strain PZS_A08

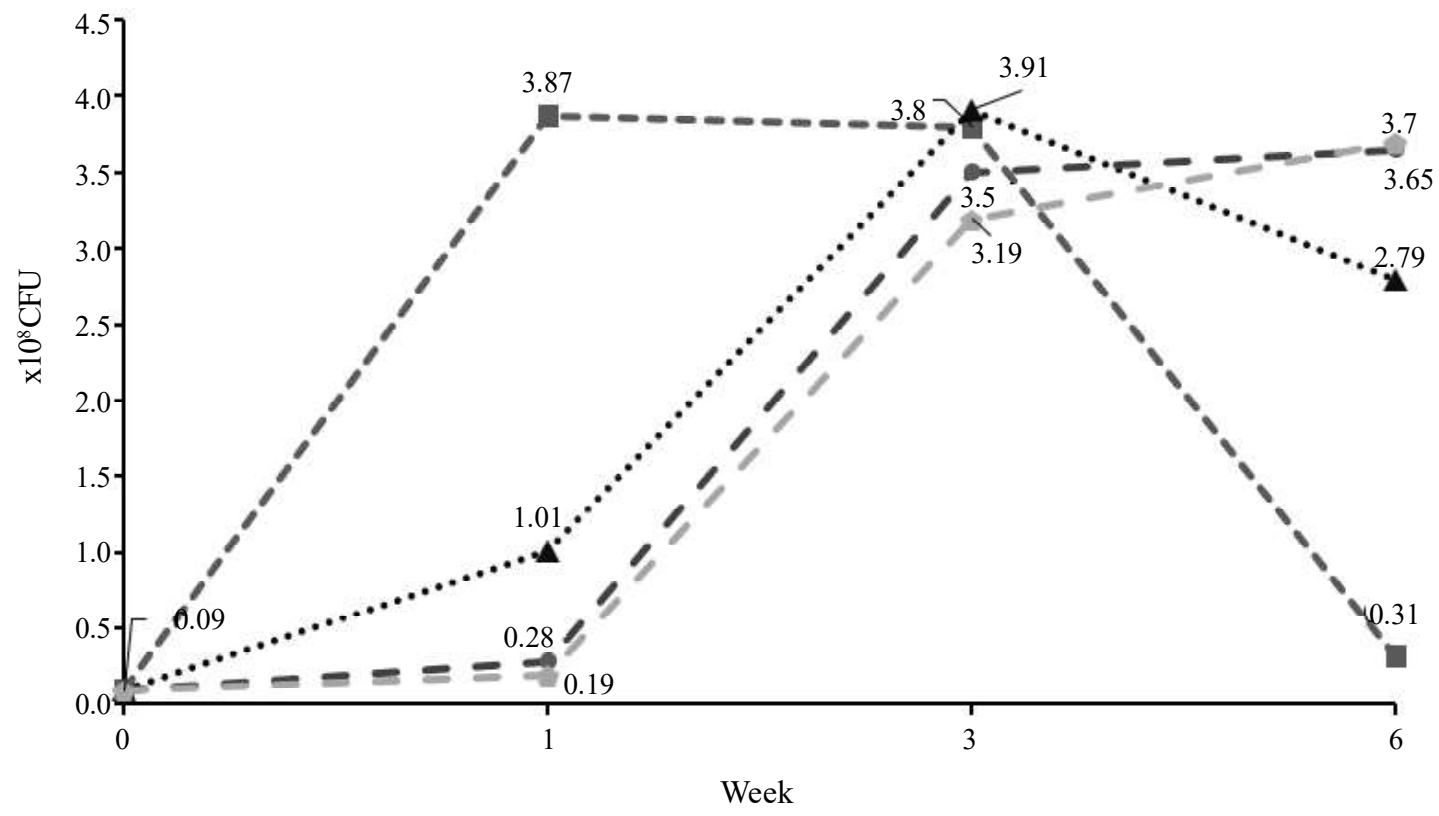

Figure 3. The viability of Bradyrhizobium sp. strain PZS_A08 on zeolite and molasses. - a

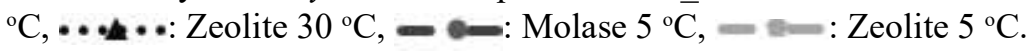


on Indigofera zolingeriana. Application of Bradyrhizobium sp. strain PZS_A08 has been shown to increase plant growth and decrease NPK fertilizer by up to $50 \%$, using zeolite and molasses. Although it had no significant effect on increasing plant growth, the use of zeolites compared to molasses caused an increase in the number of nodules and root biomass. Also, molasses as a carrier material have a lower ability to maintenance microbial populations than the use of zeolites at room temperature. Although this is a relatively minor factor, zeolite as a carrier for Bradyrhizobium is more recommended for biofertilizer production than molasses used.

\section{ACKNOWLEDGMENTS}

The authors would like to acknowledge the Soil Biotechnology Laboratory, Soil Science and Land Resources Department Faculty of Agriculture, IPB University, to fund this research project and provide necessary facilities as part of the environmental biotechnology course.

\section{REFERENCES}

Abd El-Fattah Dalia A, WE Eweda, MS Zayed and MK. Hassanein. 2013. Effect of carrier materials, sterilization method, and storage temperature on survival and biological activities of azotobacter chroococcum inoculant. Ann Agr Sci 58: 111-18. http://dx.doi.org/10.1016/j.aoas.2013.07.001.

Abdullah L, DDS Budhie and AD Lubis. 2011. Pengaruh aplikasi urin kambing dan pupuk cair organik komersial terhadap beberapa parameter agronomi pada tanaman pakan Indigofera sp. Pastura: J Trop Forage Sci 1: 5-8. (in Indonesian).

Brar SK, SJ Sarma and E Chaabouni. 2012. Shelf-life of biofertilizers: an accord between formulations and genetics. J Biofertil Biopestici 3: 000e109. doi:10.4172/2155-6202.1000e109

Bünger W, A Sarkar, JL Grönemeyer, J Zielinski, R Revermann, T Hurek and B Reinhold-Hurek. 2021. Root . Front Microbiol 12: 611704. doi:10.3389/ fmicb.2021.611704

Czaban J, A Gajda and B Wróblewska. 2007. The Motility of Bacteria from Rhizosphere and Different Zones of Winter Wheat Roots. Pol J Environ Stud 16: 301-308.

Dêbska B, J D ${ }^{3}$ ugosz, A Piotrowska-D ${ }^{3}$ ugosz and M Banach-Szott. 2016. The impact of a bio-fertilizer on the soil organic matter status and carbon sequestration-results from a field-scale study. J Soil Sediment 16: 2335-2343.

Devendra C and JB Liang. 2012. Conference summary of dairy goats in asia: current status, multifunctional contribution to food security and potential improvements. Small Rumin Res 108: 1-11. http:// dx.doi.org/10.1016/j.smallrumres.2012.08.012.
Duan C, P Shi, N Zong, J Wang, M Song and X Zhang. 2019. Feeding solution: crop-livestock integration via crop-forage rotation in the southern tibetan plateau. Agric Ecosyst Environ 284: 106589. https:/ /doi.org/10.1016/j.agee.2019.106589.

Faradillah F, R Mutia and LAbdullah. 2015. Substitution of soybean meal with indigofera zollingeriana top leaf meal on egg quality of cortunix cortunix japonica. Media Peternakan 38: 192-197. (in Indonesian).

Garcha S, R Kansal and SK Gosal. 2019. Molasses growth medium for production of rhizobium sp. based biofertilizer. Indian J Biochem Biophys 56: 378-383.

Gopalakrishnan S, A Sathya, R Vijayabharathi, RK Varshney, CLL Gowda and L Krishnamurthy. 2015. Plant growth promoting rhizobia: challenges and opportunities. 3 Biotech 5: 355-377. http:// dx.doi.org/10.1007/s13205-014-0241-x.

Hassen A, NFG Rethman, Z Apostolides and WA Van Niekerk. 2008. Forage production and potential nutritive value of 24 shrubby indigofera accessions under field conditions in South Africa. Trop Grasslands 42: 96-103.

Hutapea PS, LAbdullah, PDMH Karti and I Anas. 2018. Improvement of Indigofera Zollingeriana production and methionine content through inoculation of nitrogen-fixing bacteria. Trop Anim Sci J 41: 37-45.

Kaljeet S, F Keyeo and H Amir. 2011. The temperature on survivability of rhizobial inoculant. Asian J Plant Sci 10: 331-337.

Khandare RN, R Chandra, N Pareek and KP Raverkar. 2015. Effect of varying rates and methods of carrierbased and liquid azotobacter and psb biofertilizers on yield and nutrient uptake by wheat (Triticum Aestivum L.) and soil properties. J Indian Soc Soil Sci 63: 436-441.

Koten BB, R Wea, RD Soetrisno, N Ngadiyono and B Soewignyo. 2014. Konsumsi nutrien ternak kambing yang mendapatkan hijauan hasil tumpangsari arbila (Phaseolus Lunatus) dengan sorgum sebagai tanaman sela pada jarak tanam arbila dan jumlah baris sorgum yang berbeda. J Ilmu Ternak 1: 38-45. (in Indonesian).

Larrainzar E, I Villar, MC Rubio, C Pérez-Rontomé, R Huertas, S Sato, JH Mun and M Becana. 2020. Hemoglobins in the legume-rhizobium symbiosis. New Phytol 228: 472-484. doi: 10.1111/nph.16673

Ledermann R, B Emmenegger, JM Couzigou, N Zamboni, P Kiefer, JA Vorholt and HM Fischer. 2021. Bradyrhizobium diazoefficiens requires chemical chaperones to cope with osmotic stress during soybean infection. mBio 12: e00390-21. doi.org/ 10.1128/mBio.00390-21.

Leggo PJ. 2015. The efficacy of the organo-zeolitic biofertilizer. Agrotechnology 06: 1-4.

Lindström, Kristina and SA Mousavi. 2020. Effectiveness of nitrogen fixation in rhizobia. Microb Biotechnol 13: 1314-1335. 
Liu YH, ET Wang, YS Jiao, CF Tiana, L Wang, ZJ Wang, JJ Guana, RP Singh, WX Chen and WF Chen. 2018. Symbiotic characteristics of bradyrhizobium diazoefficiens usda 110 mutants associated with shrubby sophora (Sophora Flavescens) and soybean (Glycine Max). Microbiol Res 214: 19-27. doi.org/10.1016/j.micres.2018.05.012.

Maróti $G$ and É Kondorosi. 2014. Nitrogen-fixing rhizobium-legume symbiosis: are polyploidy and host peptide-governed symbiont differentiation general principles of endosymbiosis?. Front Microbiol 5: 1-6.

Mohamed ASA, AK Khider and S Muniandy. 2016. Effect of storage temperature, duration and types of biofertilizer carriers on survival and numbers of bacterial strains Bacillus megaterium var. phosphaticum, Azotobacter chroococcum, Rhizobium leguminosarum and Transformant, Transconjugant B. megaterium var. phosphaticum. International conference on agricultural, food, biological and health sciences (AFBHS-16), pp. 99104. doi:10.17758/eap.eap816211.

Radzman N, MA Djordjevic and N Imin. 2013. Nitrogen modulation of legume root architecture signaling pathways involves phytohormones and small regulatory molecules. Front Plant Sci 4: 1-7.

Mukhtar S, I Shahid, S Mehnaz and KA Malik. 2017. Assessment of two carrier materials for phosphate solubilizing biofertilizers and their effect on growth of wheat (Triticum Aestivum L.). Microbiol Res 205: 107-117. http://dx.doi.org/ 10.1016/j.micres.2017.08.011.

Nguyen HP, H Miwa, T Kaneko, S Sato and S Okazaki. 2017. Identification of Bradyrhizobium elkanii genes involved in incompatibility with Vigna radiate. Genes 8: 374. doi:10.3390/genes8120374

Oliveira FLN, WS Oliveira, NP Stamford, EVN Silva, CERS Santos and ADS Freitas. 2017. Effectiveness of biofertilizer enriched in $\mathrm{n}$ by Beijerinckia indica on sugarcane grown on an ultisol and the interactive effects between biofertilizer and sugarcane filter cake. J Soil Sci Plant Nutr 17: 1040-1057.
Nurhayu A and D Pasambe. 2016. Indigofera sebagai substitusi hijauan pada pakan sapi potong di kabupaten bulukumba sulawesi selatan. Seminar Nasional Peternakan 2: 52-56. (in Indonesian).

Pommeresche R and S Hansen. 2017. Examining root nodule activity on legumes. Fertil Crop Technical. 1-4. Available at: http://orgprints.org/31344/1/tnwp5-root-nodules_final_2017.pdf. (Accessed on May 5, 2021).

Santos MS, MA Nogueira and M Hungria. 2019. Microbial inoculants: reviewing the past, discussing the present and previewing an outstanding future for the use of beneficial bacteria in agriculture. AMB Express 9. https://doi.org/10.1186/s13568-019-0932-0.

Shravani K, S Triveni, PC Latha and CK Damodara. 2019. Evaluation of shelf life and quality of carrier and liquid-based biofertilizers. Int J Microbiol Res 11: 1598-1601.

Simanuhuruk K and J Sirait. 2009. Pemanfaatan leguminosa pohon Indigofera sp. sebagai pakan basal kambing Boerka fase pertumbuhan. Seminar Nasional Peternakan dan Veteriner 2009, pp. 449454. (in Indonesian).

Tabacco E, L Comino and G Borreani. 2018. Production efficiency, costs and environmental impacts of conventional and dynamic forage systems for dairy farms in Italy. Eur J Agron 99: 1-12. https://doi.org/ 10.1016/j.eja.2018.06.004.

Tarigan A and SP Ginting. 2011. Pengaruh taraf pemberian Indigofera sp. terhadap konsumsi dan kecernaan pakan serta pertambahan bobot hidup kambing yang diberi rumput Brachiaria Ruziziensis. J Ilmu Ternak dan Veteriner 16: 25-32. (in Indonesian).

Tinsley TL, S Chumbley, C Mathis, R Machen and BL Turner. 2019. Managing cow herd dynamics in environments of limited forage productivity and livestock marketing channels: an application to semiarid Pacific Island beef production using system dynamics. Agric Syst 173: 78-93. doi.org/10.1016/ j.agsy.2019.02.014. 